\title{
Factors That Influence Entrepreneur Success In City Of Medan
}

\author{
Selwendri, Onan Marakali Siregar \& Muhammad Arifin Nasution
}

Faculty of Social and Political Sciences, University of Sumatera Utara, Indonesia

Received:July 07, 2020 ; Reviewed:August 16, 2020 ; Accepted: October 12, 2020

*Coresponding Email:selwendri@usu.ac.id

\begin{abstract}
The importance of entrepreneurship in society is not just to make improvements and changes in quality of life community, but also also proven to play a significant role in realizing the quality of the people and the nation. This study aims to determine the factors that determine the success of entrepreneurs in entrepreneurs in the city of Medan. This study uses quantitative research methods through the provision of questionnaires using predetermined indicator indicators in addition to extracting information through indepth interviews. The results of the study show that lifestyle variables influence the success of an entrepreneur. In addition, lifestyle variables have a significant effect onsuccess variables entrepreneurial. So, the hypothesis is acceptable, namely the existence of partial lifestyle influences onsuccess intentions entrepreneurial. The results of partial tests explain that psychological capital variables (X2) have a positive effect. In addition, psychological capital variables have a significant effect onsuccess variables entrepreneurship. So, the hypothesis can be accepted, namely the influence of psychological capital partially onsuccess intentions. Entrepreneurial That individual talent variable (X3) has a positive effect and individual talent variables influencesuccess. Entrepreneur Individual talent variables have a significant effect onsuccess variables entrepreneurship. So, hypothesis 3 is acceptable, that is, the influence of individual talents partially on theintention to succeed entrepreneur's.
\end{abstract}

Keywords: Social Media, Business Opportunity, Entrepreneurship

How to Cite: Sulwendri, Siregar, O.M., \& Nasution, M.A. (2020). Factors That Influence Entrepreneur Success In City Of Medan. Journal of Education, Humaniora and Social Sciences (JEHSS). 3 (2): 281-285. 


\section{INTRODUCTION}

Entrepreneurship has several important roles in the economy including creating new jobs, increasing economic growth and national income, reducing economic disparities that occur between high-income and low-income communities, fostering community independence in the economic field so that it does not depend on other parties and foster creativity. In carrying out entrepreneurial activities, everyone has the opportunity to entrepreneurship, but when people do entrepreneurial activities, the results of entrepreneurial activities between one another are not necessarily the same, although using the same techniques in running entrepreneurial activities, because success in entrepreneurship is not only determined by technical factors. When viewed from age, everyone also has the potential to become an entrepreneur, both young and old, can run entrepreneurial activities.

There are some entrepreneurs who start a business at an age that is mature enough due to a termination of employment or because they do not have activities at retirement, so they start running entrepreneurial activities. Although the best age in starting entrepreneurship is from a age the abilityto learn, have new creative ideas and keep abreast of information technology are on the cusp, besides at a young age the risk is smaller if there are obstacles in entrepreneurship because they are still not married or young families with small children (Lubis et al., 2020; Mora et al., 2020; Syardiansah et al., 2020; Haryati et al., 2019)

In recent years there has been an increase in public interest in entrepreneurship in North Sumatra Province, this is proven by recording where there is an increase in the number of people working as entrepreneurs. The results of the 2016 economic census carried out by the North Sumatra (North Sumatra) Central Statistics Agency (BPS) said the number of businesses grew by $11.5 \%$ or 12,000 businesses from the previous amount of 1.06 million to 1.18 million businesses. This growth occurs within 10 years.

From the data collection, it can be seen that the most dominant business is the trade sector business with a total of almost $47.20 \%$ of the total business. This development is supported by the development of population and the growth of modern businesses such asbusinesses online. "Online business has contributed to the increase in economic activity in Indonesia in recent years. As many as 1.16 million businesses or $98.55 \%$ are small-scale micro- enterprises (MSEs) and 17,120 (1.45\%) are medium-sized business enterprises (UMB). In line with the distribution of the number of businesses, the labor distribution map illustrates the same thing. From the trade business category, the processing industry, the provision of accommodation, as well as food and beverages, became a place of livelihood of two-thirds of the total workforce in North Sumatra which amounted to 2.1 million people. While other business categories each only contribute under $10 \%$.

Meanwhile for the City of Medan according to the status of the main job as a young entrepreneur or self-employed experienced an increase with the number $1,026(16.64 \%)$ in February 2016 to 1,069 (17.1\%) in February 2017. While the number and percentage of the population of Medan City by status the main job as a worker / employee / employee decreased with a total of 2,371 (38.45\%) in February 2016 to 2,230 (35.48\%) in February 2016.

Phenomenon of the increasing presence of young entrepreneurs also increases the number of business professions in general. Various factors that influence entrepreneurial intelligence provide knowledge for entrepreneurs such as lifestyle, psychological capital and individual talents. These factors are factors that determine a person's success in work as an entrepreneur. Therefore, these factors become the focus in this research proposal.

Based on the background described, the formulation of the problem in this study is whether the factors that influence the success of entrepreneurs in Medan city, then the identification of the problem in this research is does lifestyle have a significant positive effect on the success of the entrepreneur,does psychological capital have a significant positive effect onsuccess entrepreneur, do individual talents have a significant positive effect on 
success entrepreneur, how do you influence the contribution of lifestyle, psychological capital and individual talents tosuccess entrepreneurial?

\section{RESEARCH METHODS}

Population in this study were entrepreneurs in Medan City who were members of KADIN and HIPMI, North Sumatra which numbered around 150 people. Sekaran (2006) quoted from Roscoe (1975) The sample size that is feasible in the study is between 30 to 500. If the research will do multivariate analysis (multiple correlations or regression), the number of sample members is at least 10 times the number of variables examined. The dependent and free variables in this study were 4 (four) so that $10 \times 4=40$. Based on the above explanation, the minimum number of samples used in this study were 40 people. To facilitate calculation, the researcher took a sample of 50 respondents. In this study the authors used two data collection techniques, namely: Primary data, collection technique primary data used in this research is data obtained directly from respondents using a questionnaire. Secondary Data Secondary, data collection techniques used in this study are: Literature Study, Collection of data obtained from books, scientific works and opinions of experts who are competent and have relevance to the phenomenon to be studied. Documentation Study, Data collection using written notes or documents, drawings, or other objects related to the phenomenon under study.

Test Methods for Test Instruments were, Validity and Reliability conducted to test whether the questionnaires distributed were appropriate to be used as research instruments. Validity and Reliability Tests were conducted on respondents. This is done so that the data obtained is valid and reliable. Classical Assumption Test The classical, Assumption requirements must be fulfilled by multiple regression models before the data is analyzed are as follows: Normality, Test Normality Test aims to test whether in the regression model, dependent variable, independent variable, or both have normal distribution or not. TestHeteroskidastity, heteroskedastisitas test aims to test whether there is inequality in the regression model varian of the residuals of the observations to other observations. If the variance from residual one observation to another observation is fixed then it is called homoskedasticity and if a different variant is called heteroscedasticity. Multicollinearity Test This test is used to test whether the regression model found correlation between independent variables. If there is a correlation between independent variables, it can be said that there is a problem of multicollinearity. A good regression model should not have a correlation between independent variables. Multicolinearity test uses thecriterion Variance Inflation Factor (VIF)with the provisions:

If VIF $>10$ there is a serious problem of multicollinability.

If VIF is $<10$, there is no serious multicollinability problem.

Multiple Linear Regression Analysis

Regression Analysis is used to analyze whether independent variables (lifestyle, psychological capital, and individual talents) together influence the dependent variable, namely success entrepreneur. The equation model used in this study is:

\section{Testing Hypothesis}

$$
\mathrm{Y}=\mathrm{a}+\mathrm{b} 1 \mathrm{X} 1+\mathrm{b} 2 \mathrm{X} 2+\mathrm{b} 3 \mathrm{X} 3+\mathrm{e}
$$

After the regression model meets classical assumption requirements, it will be used to analyze regression through testing the hypothesis as follows: Partial Significance Test (Test $-t$ ), This test is conducted to find out how far the influence of one independent variable partially (individually) explains the variation of the dependent variable. The basis for decision making for partial t test in regression analysis is as follows: Based on the value of $t$ count and $t$ table, If the value of $t$ arithmetic $>t$ table, the independent variable affects the dependent variable. If the value of $t$ arithmetic $<\quad t$ table, then the independent variable has no effect on dependent variable, Based on the significance value of the output on software statistical, if the value of sig. $<0.05$, the independent variable has a significant effect on the dependent variable, if the sig value. $>0.05$, no significant effect of independent variables on the dependent variable

$\mathrm{H} 0$ is rejected if $\mathrm{t}<\mathrm{t}$ table at $\alpha=5 \% \mathrm{Ha}$ accepted if $\mathrm{t}>\mathrm{t}$ table at $\alpha=5 \%$, Significant Simultaneous Test (Test F), Kuncoro (2013 : 219) argues that F statistical test basically shows whether all independent variables included in the model have the same effect on the dependent variable. Simultaneous testing (Test-F) is done to see the effect of independent variables (lifestyle, Wwith http://mahesainstitute.web.id/ojs2/index.php/jehss Mahesainstitut@gmail.com 283

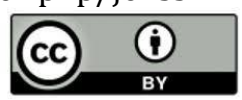


psychological capital and individual talents) on the dependent variable (success entrepreneurial) together. The Determination Coefficient, Kuncoro (2013) argues that the coefficient of determination $\left(\mathrm{R}^{2}\right)$ essentially measures how much the ability of the model in explaining the dependent variable. If $\mathrm{R}^{2}$ gets bigger (close to one), then it can be said that the influence of the independent variable $\left(\mathrm{X}_{1}, \mathrm{X}_{2}, \mathrm{X}_{3}\right)$ is large on the dependent variable (Y). This means that the model used is stronger to explain the effect of the independent variables studied on the dependent variable. Unfortunately if $\mathrm{R}^{2}$ gets smaller (near zero), then it can be said that the effect of independent variables $(\mathrm{X} 1, \mathrm{X} 2, \mathrm{X} 3)$ on the dependent variable $(\mathrm{Y})$ is getting smaller. This explains the effect of the independent variables studied on the dependent variable.

\section{RESEARCH AND RESULT}

Simultaneous test results explain that lifestyle variables (X1), psychological capital (X2), and individual talents (X3) have a positive and significant effect on the calculated $\mathrm{f}$ value $(28,631)>\mathrm{f}$ table $(2,81)$ which means variable variables lifestyle $(\mathrm{X} 1)$, psychological capital (X2), and individual talents (X3) affect the success of entrepreneurs. In addition, based on the significance value that the sig value is. $(0.00)<0.05$, the variables of lifestyle (X1), psychological capital (X2), and individual talents (X3) have a significant effect on the success variable of entrepreneurs. So, hypothesis 4 is acceptable, namely the influence of lifestyle variables (X1), psychological capital (X2), and individual talents (X3) simultaneously on entrepreneurial success intentions. The results of this study support the previous research conducted by Frese (2014) with the title "The Psychology of Entrepreneurship" which gets results that variable lifestyle, psychological capital and individual talents partially and simultaneously have a positive and significant effect on the success of entrepreneurs. Based on the distribution of respondents 'answers related to the success of the entrepreneur $(Y)$ there is an accumulation of respondents' answers of positive value (strongly agree) as much as $84 \%$ in the distribution of answers that state that "I make customer loyalty an important thing in doing business". The results of this study support the theory by Soetadi who states that successful entrepreneurs must have a strong belief that wherever their business is, they are able to run and always have confidence that the business will succeed. In addition, based on the distribution of respondents 'answers related to the success of the entrepreneur $(\mathrm{Y})$ there is an accumulation of respondents' answers with a negative value (disagree) as much as $12 \%$ in the distribution of answers that stated prioritizing creativity and innovation in doing business.

\section{CONCLUSION}

Based on the results of the study and discussion, it can be concluded as follows: The partial test results explain that lifestyle variables (X1) have a positive and significant effect on the value of $t$ count (3.859) $>t$ table (1.665) which means that lifestyle variables affectsuccess entrepreneur. In addition, based on the significance value that the sig value is. $(0.00)<0.05$, the lifestyle variable has a significant effect on the success of thevariable entrepreneur. So, hypothesis 1 is acceptable, namely the existence of a partial lifestyle influence onsuccess intentions entrepreneurial. The partial test results explain that the variable psychological capital (X2) has a positive and significant effect on the value of $t$ count (3.859)> $t$ table (1.665), which means that the variables of psychological capital affect the success of entrepreneurs. In addition, based on the significance value that the sig value is. $(0.00)<0.05$, the psychological capital variable has a significant effect on the success variable of entrepreneurs. So, hypothesis 2 is acceptable, namely the influence of psychological capital partially onsuccess intentions entrepreneurial. The partial test results explain that individual talent variables (X3) have a positive and significant effect on the value of $t$ count (3.859) > $t$ table (1.665), which means that individual talent variables affect the success of entrepreneurs. In addition, based on the significance value that the sig value is. $(0.00)<0.05$, the individual talent variables have a significant effect on the success variable of 
entrepreneurs. So, hypothesis 3 is acceptable, namely the influence of individual talents partially onsuccess intentions entrepreneurial.

\section{REFERENCES}

Baron, (2013). "Why Entrepreneurs Often Experience Low, Not High, Levels of Stress: The Joint Effects of Selection and Psychological Capital". Journal of management. Vol 42, No 3. Hal 742-768

Haryati, E., Suharyanto, A. Hasmayni, B. \& Siregar, F.H. (2019). The Effect of Work Environment and Work Stress on Employee Performance at PT Aneka Gas Industri Tbk Research Article in Proceedings of the 2nd International Conference on Social Sciences and Interdisciplinary Studies (formerly ICCSSIS), ICCSIS 2019, 24-25 October 2019, Medan, North Sumatera, Indonesia

Hickie, (2011). "The Development of Human Capital in Young Entrepreneurs". Industry \& Higher Education. Vol 25, No 6. Hal 469-481

Juliandi, (2013). Metodologi Penelitian Kuantitatif: Untuk Ilmu-Ilmu Bisnis.Medan: M2000.

Kuncoro, (2013). Metode Riset Untuk Bisnis dan Ekonomi. Jakarta: Erlangga. Maxwell, 2017. Beyond Talent. Surabaya: Mic Publishing.

Lubis, F.R.A., Suharyanto, A., Effendy, R., Meidasari, V.E., Shahnaz, L. (2020). Role of Facebook Advertising in Promoting Tourism in Asia. International Journal of Psychosocial Rehabilitation

Marchant, (2011). "Understanding Lifestyle Entrepreneurs and Digging Beneath the Issue of Profits: Profiling Surf Tourism Lifestyle Entrepreneur in Ireland". Tourism Planning \& Development. Vol 8, No 2. Hal 171-183

Mora, Z., Suharyanto, A., Yahya, M., (2020). Effect of Work Safety and Work Healthy Towards Employee's Productivity in PT. Sisirau Aceh Tamiang, Budapest International Research and Critics Institute, 3(2): 753-760.

Mottiar, (2007). "Lifestyle Entrepreneur and Spheres of Inter-firm Relations". Entrepreneurship and Innovation. Vol 8, No 1. Hal 67-74

Noor, (2013). Penelitian Ilmu Manajemen, Tinjauan Filosofis dan Praktis. Jakarta: Kencana.

Pasaribu, (2016). From The Perspective Of Strategic Management. Jakarta: Gramedia.

Sekaran, Uma, (2006). Metode Penelitian Bisnis. Jakarta : Salemba Empat

Soetadi, (2016). Pendidikan Kewriausahaan Melalui Pikiran Alam Sadar dan Pikiran Bawah Sadar. Medan: USU Press.

Sugiyono, (2014). Metode Penelitian Bisnis. Bandung: Alfabeta.

Syardiansah, Latief, A., Daud, M.N., Windi, \& Suharyanto, A, (2020), The Effect of Job Satisfaction and Organizational Culture on Employee Performance of the Royal Hotel in East Aceh District, Budapest International Research and Critics Institute, 3(2): 849-857.

Zou, (2016). "Psychological Capital and Conflict Management In The Entrepreneur -Venture Capitalist Relationship in China: The Entrepreneur Perspective". Internasional Small Business Journal. Vol 34(4). Hal 446- 467 